\title{
Quality Improvement of White Pepper with Processing through Optimizing the Ratio of Starter Culture from Acetobacter sp., Bacillus subtilis, and Bacillus cereus
}

\author{
Kirana Sanggrami Sasmitaloka*, Hernani \\ Indonesian Center for Agricultural Postharvest Research and Development, Bogor, Indonesia
}

ARTICLE INFO

Article history:

Received January 24, 2021

Received in revised form September 15, 2021

Accepted October 5, 2021

\section{KEYWORDS:}

Acetobacter sp.,

Bacillus sp.,

fermentation,

quality improvement,

white pepper

\begin{abstract}
Fermentation process using known microbial species can be exploited for the processing of white pepper. It is expected to generate quality of white pepper in a short period soaking time. This research aimed to study characteristics of white pepper through a fermentation process by addition of combination isolates of Acetobacter sp., B. subtilis, and B. cereus. After threshing, $2 \mathrm{~kg}$ of fresh pepper berries was soaked in water mixed with starter culture. The experiment used a completely randomized design, two replications. The treatment consisted of: A) starter culture ratio of Acetobacter sp.: B. subtillis: B. cereus $(\mathrm{A} 1=0: 0: 0 ; \mathrm{A2}=$ 1:1:1; $A 3=2: 1: 1 ; A 4=1: 2: 1 ;$ and $A 5=1: 1: 2)$ and soaking time $(B 1=5$ and $B 2=7$ days). Fermented pepper was decorticated, washed, and dried. The best treatment was fermented for 7 days with the combination isolates of Acetobacter sp., $B$. subtilis, and $B$. cereus with ratio $2: 1: 1$. This condition produced white pepper in fulfilling in requirement of SNI standards with piperine and essential oil contents and TPC of $5.95 \%, 2.95 \%$ and $1.1 \times 10^{2} \mathrm{CFU} / \mathrm{g}$, respectively. This process is expected to generate high quality of white pepper in a short soaking time.
\end{abstract}

\section{Introduction}

Pepper (Piper nigrum L.) is one of the oldest spices in the world. It has a mild flavour, pungency and light color (van Ruth et al.2019). Due to their characteristics, there is a growing demand for white pepper in the markets worldwide. According to the maturity level of their harvested time and the treatment given to peppercorn, the product of pepper is classified into green, black, and white pepper. Green pepper is processed, since it is harvested in immature and process to the form of pepper in saline solution or dehydrated pepper, which provides a distinctive fruity flavor and a lower pungency than the other varieties (Favre et al. 2020).

The main product is very well-known is black and white pepper (Azman et al. 2020). White pepper is produced by removing the outer ripe berry skin (retting method), while black pepper processed by drying the unripe berries until the wrinkled skin is formed (Li et al. 2020).

\footnotetext{
* Corresponding Author

E-mail Address: kirana.sanggrami@gmail.com
}

In 2015, Indonesia became the second-largest producer and exporter of pepper in the world after Vietnam. Furthermore, Indonesia was the third highest white pep- per producer supplying 18,000 tons of white pepper after China and Vietnam (Nedspice 2015). Traditionally, white pepper in Indonesia produced by soaking the fully ripened pepper berries in water for about 2-3 weeks to decorticate the pericarp (Darwis et al. 2020). Several factors like safety, hygiene and quality (bulk density, moisture content, light berries, and microbial contamination) of white pepper are often neglected during the water retting process. Consequently, it is important to supply better quality and hygienic white pepper.

Another effective yet affordable alternative was to use microbial for fermentation. The microbial can use to degrade cellulose, pectin, and xylan of agricultural product (Ferbiyanto et al. 2015; Helianti et al. 2016; Ye et al. 2019; de Farias et al. 2020). Fermentation process using microbial species can be exploited for the processing of white pepper. Microbes are known to secrete several hydrolytic enzymes, which are capable of degrading of pericarp and produce high 
quality of white pepper with an acceptable in the international white pepper trade (Vinod et al. 2014; Sreekala et al. 2019).

A natural enzymatic activity that contributes to be decortication process, it will be produced by a combination of water and microorganism. Some literature reported that the processing of white pepper by fermentation can produce high quality of white pepper with minimal microbial contamination if using Aspergillus niger ( $\mathrm{Hu}$ et al. 2017), Bacillus cereus (Feng 2013), Bacillus subtilis (Vinod et al. 2014; Sasmitaloka and Hernani 2020), Bacillus licheniformis (Vinod et al. 2014), Acinetobacter baumanii (Vinod et al. 2014), Klebsiella pneumoniae (Vinod et al. 2014), Microbacterium barkeri (Vinod et al. 2014), and Bacillus pumilus (Sreekala et al. 2019). However, some a study have examined the processing white pepper by fermentation using combination of isolate (Sato et al. 2020). White pepper was produced from black pepper by the fermentation method using the combination isolates of B. mycoides, B. licheniformis, and B. brevis had high piperine and volatile oil content, but it still contains high moisture content and microbial contamination. Therefore, it is necessary to find the best isolate combination to produce high quality of white pepper.

Acetobacter sp. is able to produce cellulase (Ye et al. 2019) and pectinase (Aziz et al. 2019) enzymes that can decorticate the pericarp in short period. According to Vinod et al. (2014), Bacillus subtilis can produce pectinase, cellulose, xylanase, amylase, and protease. While Bacillus cereus is capable of synthesizing extracellular amylases, proteases, cellulases, and pectinase when tested with corresponding substrates like starch, casein, cellulose and pectin in agar medium (Feng 2013). Aplication of Acetobacter sp., Bacillus subtilis, and Bacillus cereus is expected to generate quality of white pepper in a short period soaking time and minimal microbial contamination. This research aimed to study characteristics of white pepper through a fermentation process by addition of combination isolates of Acetobacter sp., Bacillus subtilis, and Bacillus cereus.

\section{Materials and Methods}

\subsection{Materials}

The raw material used was fresh pepper berries (Natar 1 variety) obtained from Sukamulya Experimental Garden, Sukabumi, West Java. The microorganisms used were Acetobacter sp., Bacillus subtilis, and Bacillus cereus, which was a collection of Indonesian Center for Agricultural Postharvest Research and Development, Bogor, Indonesia. The chemical used were nutrient agar "Merck 1.05450.0500" and nutrient broth "Himedia M002500G". The main equipment used were autoclave "Hiramaya hve-50", laminar "Thermo scientific 1300 series A2", incubator "Memmert IN 110", digital balance "OHAUS PA2202C" and others.

\subsection{Methods}

\subsubsection{Raw Material Preparation}

Fresh pepper was harvested at the optimum maturity stage (age of 8-9 months) in the garden based on a study of Megat et al. (2019). It was placed in a sack and delivered to the laboratory by car. After arriving at the laboratory, it was threshed to separate the pepper from the stalk.

\subsubsection{Isolate Propagation}

The isolate used in this research were Acetobacter sp., B. subtillis, B. cereus. It was cultivated on slant nutrient agar and incubated for 48 hours at room temperature. Isolate propagation were carried out by inoculated each isolates on $9 \mathrm{ml}$ of nutrient broth and incubated for 24 hours, in order to obtain $10 \mathrm{ml}$ of isolate suspension. Then, $10 \mathrm{ml}$ of isolate suspension was inoculated with $90 \mathrm{ml}$ of NB and incubated for 24 hours.

\subsubsection{White Pepper Fermentation}

As much as $1.2 \mathrm{~kg}$ of fresh pepper berries without sorted was soaked in mixture of water and inoculum culture and fermented based on the treatment. The treatment consisted of two factors, namely starter culture ratio of Acetobacter sp.: B. subtillis: B. cereus $(A 1=0: 0: 0 ; A 2=1: 1: 1 ; A 3=2: 1: 1 ; A 4=1: 2: 1 ;$ and $A 5=1: 1: 2)$ and soaking time $(B 1=5$ and $B 2=7$ days $)$. After soaked, fermented pepper was decorticated, washed, and dried by oven-dried at $50^{\circ} \mathrm{C}$.

\subsubsection{Analysis}

White pepper analysed their characteristcs, i.e moisture content, bulk density, blackness berries, foreign matter, unpeeled pepper, colour, piperine content, essential oil content, and total plate count. This research was conducted by Completely Random Design (CRD), two replications. All data were subjected to the analysis of variance (ANOVA) using 
SAS version. Differences between mean values were estimated using Duncan's multiple range tests at a confidence level of $95 \%$.

\section{Results}

\subsection{Physical Characteristics}

The combination of soaking time and ratio of three isolates affected unpeeled pepper content. Unpeeled pepper content of white pepper without addition three isolates around 22.09 to $38.10 \%$, while with addition three isolates around 0.34 to $32.65 \%$. Long soaking time would produce low unpeeled pepper content. The statistical analysis stated soaking time, comparison of three isolates, and combination of this treatment were significant for their unpeeled content $(\mathrm{p}<0.05)$.

Indonesian National Standards (SNI) requires some quality characteristics of white pepper such as moisture content, bulk density, light berries, blackness berries, and foreign matter. The physical characteristics of white pepper showed in Table 1. Overall, the moisture content of white pepper fermented by combination isolates in 5-day and 7-day soaking time tended to be constant. Although white pepper soaked for 7 day had moisture content lower than white pepper soaked for 5 day. Statistical analysis showed that the ratio of three isolates, soaking time, and the combination of both were not significant for their moisture content ( $p>0.05$ ). White pepper produced from this research had a moisture content according to the required standards of grade I (moisture content max 13\%) (SNI 2013).

Soaking duration affects the bulk density of white pepper. The longer of the soaking duration tends to produce a higher bulk density (Table 1 ). Bulk density of white pepper soaked for 7 day higher than white pepper soaked for 5 day in each combination. Addition of starter culture combination though to increase their bulk density. Statistical analysis stated that the ratio of three isolates, soaking time, and the combination of both were significant for their bulk density $(\mathrm{p}<0.05)$. White pepper produced with addition of three isolates had bulk density according to the required standards of grade I (SNI 2013), while without addition of isolate had not required standards.

The light berries are white peppercorns that are lighter than normal weight. A ratio of three isolates had no significance for their light berries content ( $p>0.05$ ), while soaking time and combination soaking time and starter culture ratio were significant for their light berries $(\mathrm{p}<0.05)$. White pepper produced by soaked for 5 days has light berries content more than $2 \%$. It is not in accordance with the requirement by Indonesian National Standards (Max 2) (SNI 2013). White pepper fermented for 7 day produces light berries content according to the required standards, which addition of isolate can decrease the light berries content and including the quality grade I (SNI 2013).

Indonesian National Standards require blackness berries content max $1 \%$ for grade I and $2 \%$ for grade II (SNI 2013). This treatment produce blackness white pepper around 0.18 to $0.59 \%$, in accordance with quality grade I. Statistical analysis stated that the ratio of three isolate, soaking time, and the combination of both were significant for their bulk density $(\mathrm{p}<0.05)$.

Foreign matter of white pepper had reached the Indonesian National Standards require. The addition of isolates and fermentation time tended to decrease foreign matter content. The statistical analysis stated

Table 1. Physical characteristics of white pepper fermented by combination isolates of Acetobacter sp.: B. subtillis: B. cereus

\begin{tabular}{|c|c|c|c|c|c|c|}
\hline $\begin{array}{l}\text { Comparison of } \\
\text { Acetobacter sp: } B \text {. } \\
\text { subtillis: } B \text {. cereus }\end{array}$ & Moisture (\%) & Bulk density ( $\mathrm{g} / \mathrm{l}$ ) & Light berries (\%) & $\begin{array}{l}\text { Blackness } \\
\text { berries } \\
(\%) \\
\end{array}$ & $\begin{array}{l}\text { Foreign } \\
\text { matter } \\
(\%)\end{array}$ & $\begin{array}{l}\text { Unpeeled } \\
\text { pepper } \\
(\%) \\
\end{array}$ \\
\hline \multicolumn{7}{|l|}{ Soaking for 5 days } \\
\hline $0: 0: 0$ & $11.60^{\mathrm{a}(\mathrm{A})}$ & $506.26^{\mathrm{b}(\mathrm{B})}$ & $6.53^{\mathrm{a}(\mathrm{A})}$ & $0.36^{\mathrm{b}(\mathrm{A})}$ & $1.12^{\mathrm{a}(\mathrm{A})}$ & $38.10^{\mathrm{a}(\mathrm{A})}$ \\
\hline $1: 1: 1$ & $10.60^{\mathrm{a}(\mathrm{A})}$ & $630.85^{\mathrm{a}(\mathrm{A})}$ & $4.32^{\mathrm{ab}(\mathrm{A})}$ & $0.19^{\mathrm{b}(\mathrm{A})}$ & $0.46^{\mathrm{a}(\mathrm{A})}$ & $19.66^{\mathrm{a}(\mathrm{A})}$ \\
\hline $2: 1: 1$ & $11.00^{\mathrm{a}(\mathrm{A})}$ & $608.32^{\mathrm{a}(\mathrm{A})}$ & $2.94^{\mathrm{b}(\mathrm{A})}$ & $0.18^{\mathrm{b}(\mathrm{A})}$ & $0.75^{\mathrm{a}(\mathrm{A})}$ & $32.65^{\mathrm{a}(\mathrm{A})}$ \\
\hline $1: 2: 1$ & $10.40^{\mathrm{a}(\mathrm{A})}$ & $613.68^{\mathrm{a}(\mathrm{A})}$ & $3.89^{\mathrm{ab}(\mathrm{A})}$ & $0.30^{\mathrm{b}(\mathrm{A})}$ & $1.59^{\mathrm{a}(\mathrm{A})}$ & $22.80^{\mathrm{a}(\mathrm{A})}$ \\
\hline $1: 1: 2$ & $10.75^{\mathrm{a}(\mathrm{A})}$ & $621.42^{\mathrm{a}(\mathrm{B})}$ & $4.94^{\mathrm{ab}(\mathrm{A})}$ & $0.59^{\mathrm{ab}(\mathrm{A})}$ & $0.61^{\mathrm{a}(\mathrm{A})}$ & $26.17^{\mathrm{a}(\mathrm{A})}$ \\
\hline \multicolumn{7}{|l|}{ Soaking for 7 days } \\
\hline $0: 0: 0$ & $10.70^{\mathrm{a}(\mathrm{A})}$ & $10.70^{\mathrm{a}(\mathrm{A})}$ & $1.45^{\mathrm{a}(\mathrm{A})}$ & $0.46^{\mathrm{a}(\mathrm{A})}$ & $1.23^{\mathrm{a}(\mathrm{A})}$ & $22.09^{a(B)}$ \\
\hline $1: 1: 1$ & $9.65^{\mathrm{a}(\mathrm{A})}$ & $9.65^{\mathrm{a}(\mathrm{A})}$ & $0.13^{b(A)}$ & $0.41^{\mathrm{a}(\mathrm{A})}$ & $0.60^{\mathrm{ab}(\mathrm{A})}$ & $0.34^{\mathrm{b}(\mathrm{A})}$ \\
\hline $2: 1: 1$ & $9.90^{\mathrm{a}(\mathrm{A})}$ & $9.90^{\mathrm{a}(\mathrm{A})}$ & $0.54^{\mathrm{ab}(\mathrm{A})}$ & $0.23^{\mathrm{a}(\mathrm{A})}$ & $0.22^{\mathrm{b}(\mathrm{A})}$ & $0.82^{\mathrm{b}(\mathrm{A})}$ \\
\hline $1: 2: 1$ & $10.15^{\mathrm{a}(\mathrm{A})}$ & $10.15^{\mathrm{a}(\mathrm{A})}$ & $0.71^{\mathrm{ab}(\mathrm{A})}$ & $0.36^{\mathrm{a}(\mathrm{A})}$ & $0.22^{\mathrm{b}(\mathrm{A})}$ & $2.91^{\mathrm{b}(\mathrm{A})}$ \\
\hline $1: 1: 2$ & $9.80^{\mathrm{a}(\mathrm{A})}$ & $9.80^{\mathrm{a}(\mathrm{A})}$ & $0.57^{\mathrm{ab}(\mathrm{B})}$ & $0.20^{\mathrm{a}(\mathrm{A})}$ & $0.25^{\mathrm{b}(\mathrm{A})}$ & $1.10^{\mathrm{b}(\mathrm{A})}$ \\
\hline
\end{tabular}

the numbers followed by the same capital letter in the same column and the same lowercase letter on the same row are not significantly different based on Duncan continued test at the $5 \%$ level 
soaking time and ratio of three isolates were not significant for their foreign matter content ( $p>0.05$ ), while combination of this treatment was significant $(\mathrm{p}<0.05)$.

\subsection{Colour}

The colour of white pepper tended to be a constant. The highest level of $L$ value was resulted from 7 day soaking treatment and ratio of Acetobacter sp.: $B$. subtillis: B. cereus inoculums of 1:1:1 (42.57) (Table 2). Soaking time, ratio of three isolates, and combination of this treatment were significant for their lightness value $(\mathrm{p}<0.05)$.

Addition of three isolates increase ${ }^{\circ}$ Hue value. Whereas long soaking time would produce high ${ }^{\circ} \mathrm{Hue}$ value. Statistical analysis showed that this treatment and combination of both were not significant for their ${ }^{\circ}$ Hue (Table 3 ).

\subsection{Piperine and Essential Content}

This treatment affected their piperine content (Table 4) and essential oil content (Table 5). Soaking time and addition of Acetobacter sp., B. subtillis, $B$. cereus tended to increase their piperine and essential oil content. White pepper without addition of three isolate (ratio of $0: 0: 0$ ) had piperine content of 3.11 to $3.34 \%$ and essential oil content of 2.58 to $2.61 \%$. While white pepper with addition of three isolate (ratio of $1: 1: 1,2: 1: 1,1: 2: 1$, and $1: 1: 2$ ) had piperine content of 3.82 to $5.95 \%$ and essential oil content of 2.40 to $3.20 \%$.

Statistical analysis showed that soaking time was significant for their essential oil content $(\mathrm{p}<0.05)$ but not significant for piperine content $(p>0.05)$. Starter culture ratio of three isolate and combination of both were significant for piperine and essential oil content $(\mathrm{p}<0.05)$.

Table 2. Lightness (L) of white pepper fermented by combination isolates of Acetobacter sp.: B. subtillis: B. cereus

\begin{tabular}{|c|c|c|c|c|c|c|}
\hline \multirow{2}{*}{ Soaking time (day) } & \multicolumn{5}{|c|}{ Starter culture ratio of Acetobacter sp.: B. subtillis: B. cereus } & \multirow{2}{*}{ Averages } \\
\hline & $0: 0: 0$ & $1: 1: 1$ & $2: 1: 1$ & $1: 2: 1$ & $1: 1: 2$ & \\
\hline 5 & $36.51^{\mathrm{a}(\mathrm{A})}$ & $36.50^{\mathrm{a}(\mathrm{B})}$ & $34.80^{\mathrm{a}(\mathrm{A})}$ & $34.37^{a(A)}$ & $34.81^{\mathrm{a}(\mathrm{A})}$ & $35.40^{\mathrm{B}}$ \\
\hline 7 & $34.80^{\mathrm{b}(\mathrm{A})}$ & $42.57^{\mathrm{a}(\mathrm{A})}$ & $38.80^{\mathrm{ab}(\mathrm{A})}$ & $43.96^{\mathrm{a}(\mathrm{A})}$ & $37.01^{\mathrm{ab}(\mathrm{A})}$ & $39.43^{A}$ \\
\hline Averages & $35.65^{b}$ & $39.53^{a}$ & $36.81^{\mathrm{ab}}$ & 39.16ab & $35.91^{\mathrm{ab}}$ & \\
\hline
\end{tabular}

The numbers followed by the same capital letter in the same column and the same lowercase letter on the same row are not significantly different based on Duncan continued test at the $5 \%$ level

Table 3. ${ }^{\circ}$ Hue of white pepper fermented by combination isolates of Acetobacter sp.: B. subtillis: B. cereus

\begin{tabular}{|c|c|c|c|c|c|c|}
\hline \multirow{2}{*}{ Soaking time (day) } & \multicolumn{5}{|c|}{ Starter culture ratio of Acetobacter sp.: B. subtillis: B. cereus } & \multirow{2}{*}{ Averages } \\
\hline & $0: 0: 0$ & $1: 1: 1$ & $2: 1: 1$ & $1: 2: 1$ & $1: 1: 2$ & \\
\hline 5 & $79.26^{\mathrm{ab}(\mathrm{A})}$ & $79.73^{\mathrm{ab}(\mathrm{A})}$ & $81.81^{\mathrm{a}(\mathrm{A})}$ & $78.40^{\mathrm{b}(\mathrm{A})}$ & $80.33^{\mathrm{ab}(\mathrm{A})}$ & $81.25^{\mathrm{A}}$ \\
\hline 7 & $80.23^{\mathrm{a}(\mathrm{A})}$ & $82.05^{\mathrm{a}(\mathrm{A})}$ & $81.19^{a(A)}$ & $82.07^{a(A)}$ & $80.71^{\mathrm{a}(\mathrm{A})}$ & $79.90^{\mathrm{A}}$ \\
\hline Averages & $79.75^{a}$ & $80.89^{a}$ & $81.50^{\mathrm{a}}$ & $80.24^{\mathrm{a}}$ & $80.52^{\mathrm{a}}$ & \\
\hline
\end{tabular}

The numbers followed by the same capital letter in the same column and the same lowercase letter on the same row are not significantly different based on Duncan continued test at the $5 \%$ level

Table 4. Piperine content of white pepper fermented by combination isolates of Acetobacter sp.: B. subtillis: B. cereus

\begin{tabular}{|c|c|c|c|c|c|c|}
\hline \multirow{2}{*}{ Soaking time (day) } & \multicolumn{5}{|c|}{ Starter culture ratio of Acetobacter sp.: B. subtillis: B. cereus } & \multirow{2}{*}{ Averages } \\
\hline & $0: 0: 0$ & $1: 1: 1$ & $2: 1: 1$ & $1: 2: 1$ & $1: 1: 2$ & \\
\hline 5 & $3.34^{\mathrm{c}(\mathrm{A})}$ & $4.75^{\mathrm{a}(\mathrm{A})}$ & $4.86^{\mathrm{a}(\mathrm{B})}$ & $4.35^{\mathrm{b}(\mathrm{A})}$ & $4.69^{\mathrm{a}(\mathrm{A})}$ & $4.40^{\mathrm{A}}$ \\
\hline 7 & $3.11^{\mathrm{d}(\mathrm{A})}$ & $3.82^{\mathrm{dc}(A)}$ & $5.95^{\mathrm{a}(\mathrm{A})}$ & $5.13^{\mathrm{ab}(\mathrm{A})}$ & $4.48^{\mathrm{bc}(\mathrm{B})}$ & $4.50^{\mathrm{A}}$ \\
\hline Averages & $3.23^{d}$ & $4.28^{c}$ & $5.40^{\mathrm{a}}$ & $4.74^{\mathrm{b}}$ & $4.58^{\mathrm{bc}}$ & \\
\hline
\end{tabular}

The numbers followed by the same capital letter in the same column and the same lowercase letter on the same row are not significantly different based on Duncan continued test at the $5 \%$ level

Table 5. Essential oil content of white pepper fermented by combination isolates of Acetobacter sp.: B. subtillis: B. cereus

\begin{tabular}{|c|c|c|c|c|c|c|}
\hline \multirow{2}{*}{ Soaking time (day) } & \multicolumn{5}{|c|}{ Starter culture ratio of Acetobacter sp.: B. subtillis: B. cereus } & \multirow{2}{*}{ Averages } \\
\hline & $0: 0: 0$ & $1: 1: 1$ & $2: 1: 1$ & $1: 2: 1$ & $1: 1: 2$ & \\
\hline 5 & $2.58^{\mathrm{d}(\mathrm{A})}$ & $3.20^{\mathrm{a}(\mathrm{A})}$ & $2.59^{\mathrm{d}(\mathrm{A})}$ & $3.05^{b(A)}$ & $2.79^{c(A)}$ & $2.84^{\mathrm{A}}$ \\
\hline 7 & $2.61^{\mathrm{b}(\mathrm{A})}$ & $2.42^{\mathrm{c}(\mathrm{B})}$ & $2.95^{\mathrm{a}(\mathrm{A})}$ & $2.60^{\mathrm{b}(\mathrm{A})}$ & $2.40^{\mathrm{c}(\mathrm{B})}$ & $2.59^{\mathrm{B}}$ \\
\hline Averages & $2.59^{\mathrm{b}}$ & $2.81^{\mathrm{a}}$ & $2.77^{a}$ & $2.82^{\mathrm{a}}$ & $2.59^{b}$ & \\
\hline
\end{tabular}

The numbers followed by the same capital letter in the same column and the same lowercase letter on the same row are not significantly different based on Duncan continued test at the $5 \%$ level 


\subsection{Total Plate Count (TPC)}

Total plate count was increase during soaking time. The longer of soaking time, the higher of total plate count. The fermentation process by addition of three isolates could reduce the total plate count of white pepper. White pepper produced by fermentation process day without addition isolate $(0: 0: 0)$ for 7 day had total plate count of $6.58 \log \mathrm{CFU} / \mathrm{g}$, while for 5 day fermentation had total plate count of $2.53 \log \mathrm{CFU} / \mathrm{g}$. The lowest total plate count was $2.00 \mathrm{log} \mathrm{CFU} / \mathrm{g}$ which produce on the treatment of 5 day soaking time with starter culture ratio of 2:1:1 (Acetobacter sp.: B. subtillis: B. cereus). Statistical analysis showed that only soaking time was significant for total plate count $(\mathrm{p}<0.05)$.

\subsection{Flavor}

The best treatment was fermented for 7 days with the combination isolates of Acetobacter sp., $B$. subtilis, and $B$. cereus with a ratio 2:1:1. From the best treatment was identified for the aroma such as, caryophyllene, 3-carene, D-limonen, sabinene, deltaelemene, $\alpha$ and $\beta$-phellandrene, 4-chlorobuten-3-yne, (E)-.beta.-famesene, $\beta$-Phellandrene, Isospathulenol, o-Cymene, Trans- $\beta$-ocimene, copaene, $L-\alpha$-terpineol and caryophyllene oxide (Figure 3 ). Therefore, it was also identified for an unpleasant odor less than $0.3 \%$, such as p-cresol, hexanoic acid, butanoic acid, piperonal, 1H-Indole, 2-methyl, linalool.

\section{Discussion}

\subsection{Physical Characteristics}

The pericarp of a fresh pepper berries consists of three sections which are the outer layer which includes skin or peel (exocarp), middle layer fleshy (mesocarp) and innermost layer (endocarp) (Rosnah and Chan 2014; Aziz et al. 2019). In white pepper production, the outer pericarp will be decorticated to obtain the pepper seeds to produce white pepper. According to Vinod et al. (2014) and Wang et al. (2019), specific microbes can help the decortication process by producing enzymes. Enzymes that work on the decortication process are pectinase and cellulose. Cellulase is responsible for the degradation of the exocarp layer, while pectinase is responsible for the degradation of the mesocarp layer (Aziz et al. 2019).

The pectin present in the middle layer fleshy (mesocarp) area of pepper skin begin to degrade enzymatically and break apart from the core (Geron et al. 2019). The dissolution of pectin due to enzymatic reaction will cause initial loosening of the structure of the cells and softening of the pepper skin. Further dissolve of the middle lamella layer by pectinase enzymes causes separation of the cells that resembles the skin loosening of mature ripe fruits (Aziz et al. 2019).

At the same time, the cellulosic cell wall starts to degrade during retting by cellulose enzymes. The pepper berries skin cells are exposed to disrupt and weaken the bonds structure by enzymatic activity. Prolonged soaking time will eventually increase the water uptake by osmosis through a semi-permeable membrane into the cell causing the cell to be stretched and swelled to its limit of elasticity (Hu et al. 2017). The longer the soaking time, the deeper of enzymatic reaction acts to degrade the pericarp cells. When the extracellular matrix (i.e. cellulose, pectins, hemicellulose) is weakened and removed by the enzyme, the protoplast of the plant cell will burst due to soak in culture solution of low osmotic potential (Aziz et al. 2019), which will lead to major damage to the structure of the plant cell wall and cause the berries skin to totally loosen from its core. It can cause the pepper berries skin to become softer and enable the peeling of pepper skin by abrasion. Pectinase and cellulose enzymes produced by Acetobacter sp., Bacillus subtilis, and Bacillus cereus could use in the decorticating process.

Generally, the length of the soaking duration would produce less unpeeled pepper content. It causes longer decortication and had produced more and more white pepper. In the present study, the cellulose and pectinase enzymes produced by combination isolates might have been responsible for the reduction in the time of the retting period.

Moisture content is an important factor affecting its tenderness, taste, freshness, and flavor (Song et al. 2019). It will affect their shelf life. High moisture content in white pepper can accelerate the growth of microbes during storage (Hidayat et al. 2009) and shortens its shelf life (Kusmiadi et al. 2017). The high and low moisture content of the white pepper is affected during the drying process. In this study, white pepper in all treatments was dried by the same method. This causes the moisture content of white pepper in all treatments was not significantly different It is less than research resulted from Vinod et al. (2014) which produce white pepper with a moisture content around $11-12 \%$ from fermentation using Bacillus subtilis, Thankamani and Giridhar (2004) which had moisture content of $15 \%$ from fermentation using combination isolate of B. mycoides, B. licheniformis, and B. brevis, and Ashari et al. (2014) with a moisture content of $15 \%$ by fermentation using commercial enzyme. 
Bulk density is one of the parameters that determine the quality characteristics of white pepper in the market. According to Hidayat et al. (2009), light berries can affect the bulk density. White pepper with low bulk density contains high light berries. It is make white pepper become lighter than white pepper with high bulk density.

Soaking time and ratio of isolate addition tends to affects the bulk density and light berries content. The length of the soaking time is expected to produce white pepper with high bulk density and low light berries content (Table 1 ). White pepper produces on 5 day soaking time had bulk density lower than 7 day soaking time. This could be caused by high light berries content on white pepper produced on 5 day soaking time on various starter culture ratios. The longer soaking time process, the light berries content become soften during the retting process and destroyed in the decorticating process. This result also shows that the addition of combination isolate in various comparisons can accelerate the decorticating process. It can speed up the softening process of the light berries and destroy during decorticating and washing process. Eventually, the light berries content in white pepper becomes low and bulk density become high. The bulk density of white pepper in this study was higher than Vinod et al. (2014), which produce white pepper by fermentation process using Bacillus subtilis with bulk density around 557 to $570 \mathrm{~g} / \mathrm{l}$. This shows that the use of isolate combinations with various ratio can improve the quality of the white pepper produced.

The maturity level of fresh pepper as raw material can affect the formation of blackness berries. Megat et al. (2019) and Kusmiadi et al. (2017) reported that mature pepper physiologically will produce white pepper with low blackness berries content. It was confirmed that one of the causes of the formation of blackness berries in this study is the maturity level of fresh pepper berries, which was the raw material used in this research unsorted between mature and immature (also picked by farmers) fresh pepper. Generally, a stalk of fresh pepper can bear both immature and mature fruits at the same time. Besides that, blackness berries also caused by enzymatic browning by fermentation and oxidation of phenolic compounds (Rathnawathie and Buckle 1984; Dhas and Korikanthimath 2003; Kusmiadi et al. 2017). White pepper produced by fermentation for 5-day soaking time had blackness pepper higher than 7-day soaking time. According to Usmiati and Nurdjannah (2006), too short soaking time can cause the outer pepper skin become not soft enough, so that a browning process occurs during the peeling and produces white pepper with a brownish colour.
Foreign matter is other things that are not white pepper seeds, such as stalks, skin, rocks, sand or soil. It was suspected that foreign matter in this study comes from the pepper stalks carried during the fermentation, washing and drying processes. Nevertheless, the foreign matter of white pepper had reached the Indonesian National Standards require which is max 1 for grade I and max 2 for grade II (SNI 2013).

\subsection{Colour}

Colour is an early indicator to assess the quality of white pepper. The desired colour of white pepper is yellowish white or cream, which means it has a high lightness value. According to Megat et al. (2019), maturity of fresh pepper berries affect to the colour of white pepper produced. Furthermore, colour of products can occurs by many reactions during food processing, such as pigmen degradation, browning reactions, changes in the distribution and structure of the bioactive compounds, and others (Bayram et al. 2004). Generally, white pepper production by retting process of fresh pepper berries is the formation of blackness berries colour.

The color of white pepper product by fermentation process was giving little brownish, according to the $\mathrm{L}$ value, ${ }^{\circ} \mathrm{Hue}$, and visual appearance. Baldevbhai and Anand (2012) and Hunter Laboratories (2012) stated that the $\mathrm{L}$ numbers of $0-50$ indicating dark colour and 51-100 indicating light colour. Based on Figure 1, white pepper treated by fermentation process showed a dark colour. This is confirmed by the results of the $L$ value 34.37 to 42.57 (dark colour). The blackening may be attributed to the oxidation of phenols or the Maillard reaction during the fermentation process (Waje et al. 2008). Furthermore, Mustafa et al. (2015) state that decorticating activity in the fermentation process occurs by microorganisms would produce oxygen in the metabolic process. It can convert diphenol, aminophenol and diaminobenzen compounds to produce melanin (brown pigment) and occurs browning reaction that produces a reddish-brown colour.

White pepper fermented by combination isolate had Hue value around $79.26-82.07^{\circ} \mathrm{Hue}$. The Hue value in the range of $54-90^{\circ}$ is in the reddish-yellow chromaticity area (Hunter Laboratories 2012). The closer to the $90^{\circ}$, the closer to the yellow color the chromaticity will be. Soaking time could increase Hue value. Long soaking time could soften the pepper skin and inhibit the browning reaction. The blackness berries color is the pepper that unpeeled. It has difficult to decorticate the pepper skin because the pepper's skin is not soft. The highest Hue value is found in treatment 7-day soaking time and combination of 


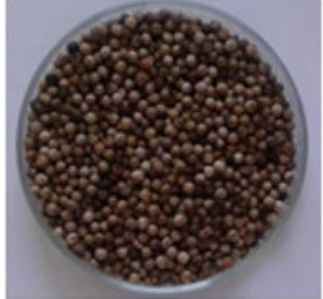

5 days, 0:0:0

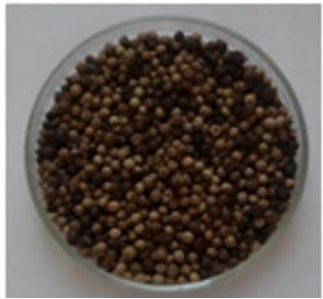

7 days, 0:0:0

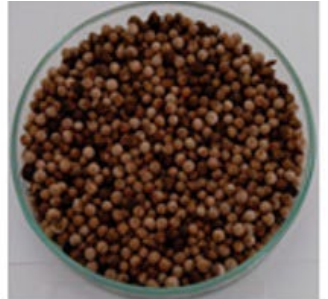

5 days, $1: 1: 1$

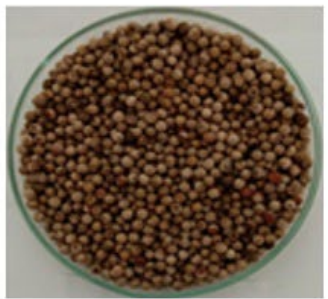

7 days, $1: 1: 1$

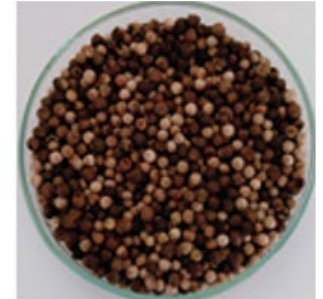

5 days, 2:1:1

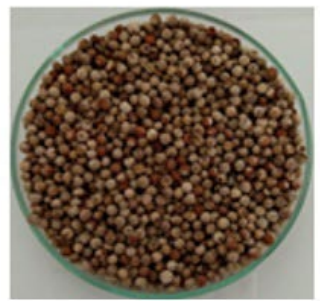

7 days, $2: 1: 1$



5 days, $1: 2: 1$

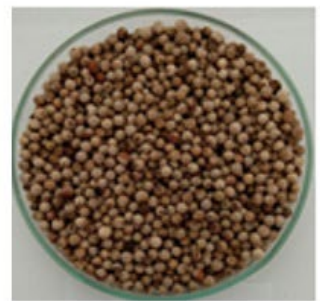

7 days, $1: 2: 1$

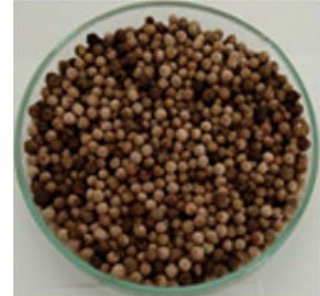

5 days, $1: 1: 2$

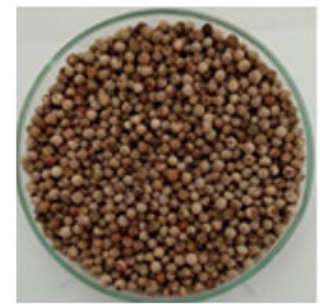

7 days, $1: 1: 2$

Figure 1. White pepper produced from various fermentation times and combinations of isolates (Acetobacter sp.: B. subtilis: B. cereus)

Acetobacter sp., Bacillus subtilis, and Bacillus cereus with ratio $1: 2: 1$. Almost the same as research result of Rosnah and Chan (2014), which produce white pepper by enzymatic retting for 15 day soaking time with Hue value of 83.77 . White pepper produced by 7-day soaking time with combination isolate addition have a colour of creamy white (Figure 1 ), while white pepper produced by 5 -day soaking duration with combination isolate addition have a dark colour (Figure 1).

\subsection{Piperine and Essential Oil Content}

The quality of white pepper depends on the content of piperine for the pungent test (Mustafa et al.2015) and essential oil for aroma (Mamatha et al. 2008) (Sreekala et al. 2019). Piperine, as the most abundant alkaloid in pepper, has beneficial health and therapeutic effects. Fermentation process of white pepper tends to increase the piperine content. Acetobacter sp., $B$. subtilis, and $B$. cereus can secrete hydrolytic enzymes specific to degrade the pectin and cellulose of pepper skin (Mohammadkazemi et al. 2015; Aziz et al. 2019). It would soften the pepper skin without degrades the alkaloid compounds. White pepper produced by suitable soaking time and combination of isolates can produce high levels of piperine. The higher piperine content in white pepper was found in the treatment of 7-day soaking duration and combination of isolates Acetobacter sp., B. subtilis, and B. cereus with ratio of $2: 1: 1(5.95 \%)$. The piperine content produced in this study was higher than other study. Vinod et al. (2014) produces white pepper from fermentation process using Bacillus subtilis WP38 isolate with a piperine content of 3.4\%. While Zhihao et al. (2011) produces white pepper fermented using Bacillus cereus with a piperine content of 4,25\%. Furthermore, Sasmitaloka and Hernani (2020) produces white pepper with piperine content of $1.45 \%$ by fermentation process of Bacillus subtilis. This suggests that the use of a combination of isolates is proven to be effective in producing white pepper with high piperine content.

The essential oil of white pepper is a mixture of many volatile chemical compounds in while pepper. The component consists of $\alpha$-pinene, $\beta$-pinene, limonene, myrcene, linalool, $\alpha$-phellandrene, sabinene, $\beta$-caryophyllene and germacrene-D which contribute to the aromatic and flavour properties of pepper (Singh et al. 2013). As well as piperine content, fermentation process also tends to increase the essential oil content. Combination of isolate suspected to produces high essential oil content. The specific characteristics of the enzymes secreted by each isolate are thought to cause the degradation process only occurs on pectin and cellulose without essential oil. The higher essential oil content was found in the treatment of 5-day soaking time and combination of isolates Acetobacter sp., $B$. subtilis, and $B$. cereus with ratio of $1: 1: 1$ (3.20\%). The length of the soaking time, the lower of the essential oil content will be. The results of this study were not much different from the results of Feng (2013), which produced white pepper by fermentation process using Bacillus cereus with essential oil content of $3.26 \%$. While, Sreekala et al. (2019) produced white pepper fermented by Bacillus pumilus with essential oil content of $2.95 \%$.

\subsection{Total Plate Count (TPC)}

White pepper has to be free from pathogenic and non-pathogenic contamination i.e., bacteria, mold and 
yeast. They can cause deterioration in pepper quality. In addition, contaminated pepper can also serve as disease transmission vehicles and cause death if contaminated with harmful microorganisms, microbial toxins or environmental contaminants (Darwis et al. 2020). According to Kaur and Gautam (2019), food is considered to be spoiled when the appearance, texture, flavor and odor are changed because microbes could have entered the food.

The length of soaking time showed increasing the number of TPC. The decorticating process can degrade the cell wall of pepper skin and many substrates will be available for microbial growth (Hu et al. 2017), so that the TPC value of white pepper produced in the 7-day soaking time becomes high. This means that more microbes carry out the decay process, which has implications for the increasing availability of metabolic substrates for microbial development, making the microbial population will be highest. However, it will be decreased by the addition of a combination isolate. The most remarkable feature of white pepper produced by the fermentation process was its extremely low microbial contamination (Figure 2). They can inhibit another microbial growth during soaking. Furthermore, decreased microbial count in the final product would enhance the shelf life significantly (Thankamani and Giridhar 2004).

\subsection{Flavor}

The odor of white pepper gave an unpleasant aroma note, which is often described as cow shed-like or fecallike. The chromatogram analysis of white pepper from the best treatment showed Figure 3. It has been reported by Liu et al. (2013) that compound gave the odor like that is 3-methylindole, p-cresol, a-pinene, linalool, b-damascenone, eugenol, and skatole. Aroma is one of the essential components of spices quality, include in pepper, because it will attract consumers. The volatile aroma compounds contain in pepper species more than 270 compounds (Steinhaus and Schieberle 2005; do Carmo et al. 2012). The important compounds which gave the flavor to the pepper is limonene, $\alpha$-pinene, $\mathrm{D}$-3-carene, $\beta$-pinene, 4 -carene, terpinolene, $\alpha$-copaene,

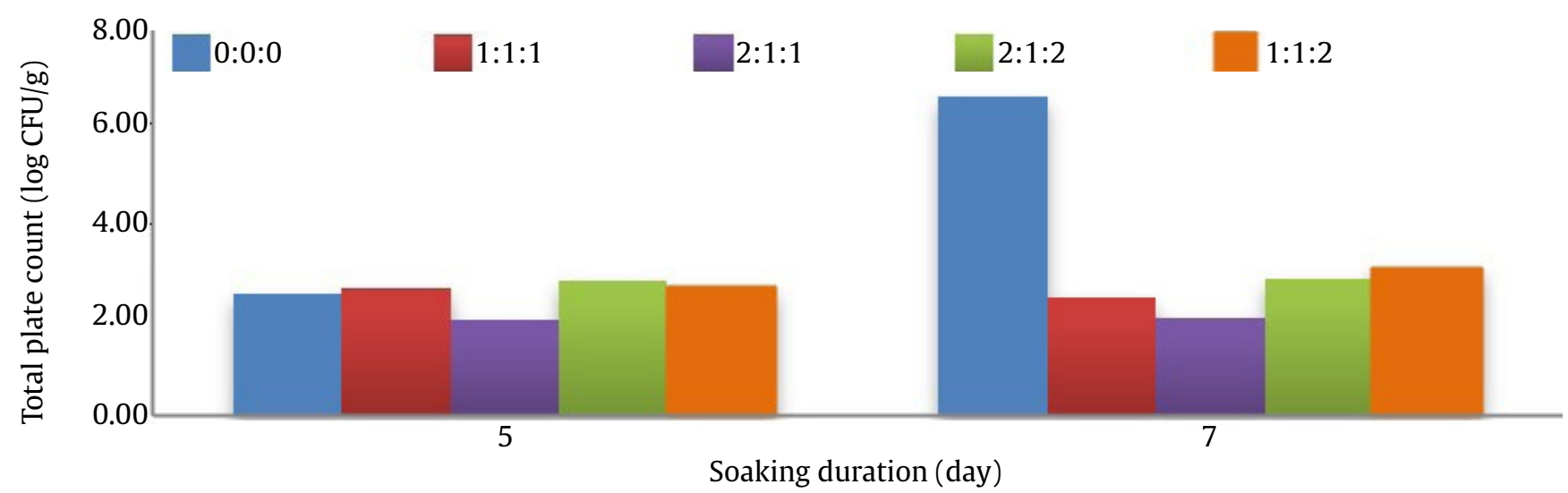

Figure 2. Total plate count of white pepper fermented by combination isolates of Acetobacter sp.: B. subtillis: B. cereus

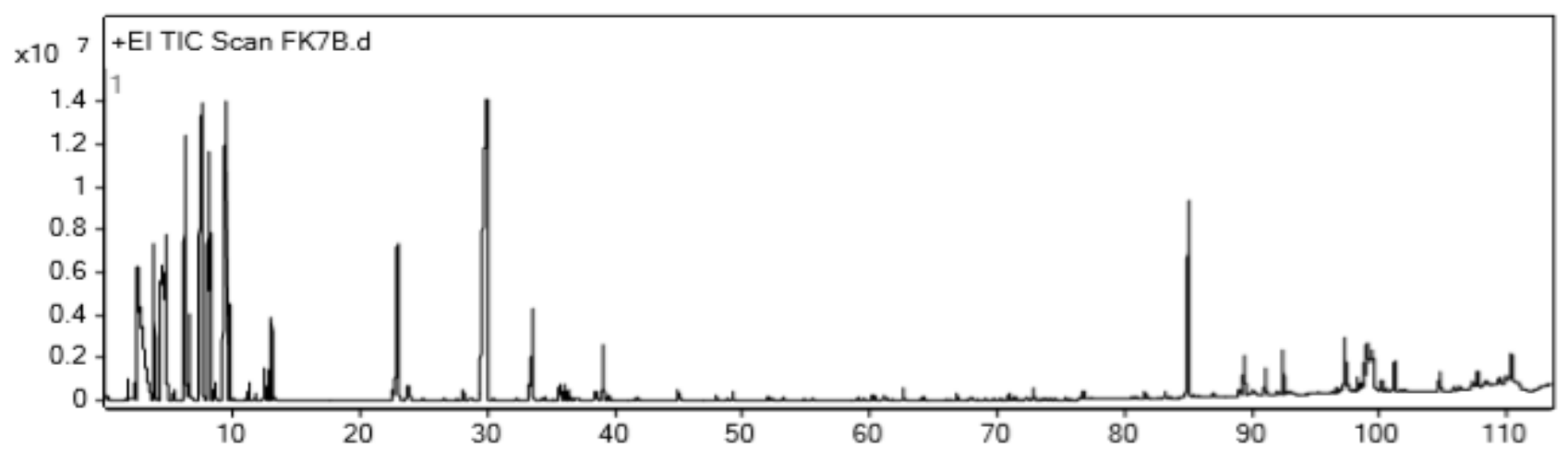

Figure 3. Chromatogram analysis of white pepper from the best treatment 
$\beta$-caryophyllene, $\alpha$ caryophyllene, and D-elemene (Hao et al. 2018).

In conclusion, combination isolates of Acetobacter sp., $B$. subtilis, and B. cereus on white pepper production is expected to generate high quality of white pepper in a short period soaking duration. The best treatment was fermented for 7 days with the combination isolates of Acetobacter sp., B. subtilis, and B. cereus with a ratio 2:1:1. This condition produced white pepper in fulfilling in requirement of SNI standards with piperine, essential oil contents and TPC of $5.95 \% 2.95 \%$, and $1.1 \times 10^{2} \mathrm{CFU} / \mathrm{g}$, respectively.

\section{References}

Ashari, M., Ibrahim, M., Husaini, A., Zulkharnain, A., 2014. Accelerated production of white pepper using integrated mechanical and enzymatic solutions in an automated machine. Key Engineering Materials. 572, 304-307. https://doi.org/10.4028/www.scientific. net/KEM.572.304

Aziz, N.S., Seng, N.S.S., Razali, N.S.M., Lim, S.J., Mustapha, W.A.W., 2019. A review on conventional and biotechnological approaches in white pepper production. Journal of the Science of Food and Agriculture. 99, 2665-2676. https://doi.org/10.1002/ jsfa.9481

Azman, P.N.M.A., Shamsudin, R., Man, H.C., Ya'acob, M.E., 2020. Kinetics of quality changes in soaking water during the retting process of pepper berries (Piper nigrum L.). Processes. 8, 1-11. https://doi.org/ doi: $10.3390 /$ pr8101255

Baldevbhai, P.J., Anand, R.S., 2012. Color image segmentation for medical images using $\mathrm{L}^{*} \mathrm{a} * \mathrm{~b} *$ color space. IOSR Journal of Electronics and Communication Engineering. 1, 24-45. https://doi.org/10.9790/2834-0122445

Bayram, M., Oner, M.D., Kaya, A., 2004. Influence of soaking on the dimensions and colour of soybean for bulgur production. Journal of Food Engineering. 61, 331-339. https://doi.org/10.1016/S0260-8774(03)00137-7

Darwis, D., Puspitasari, T., Nuryanthi, N., Kadir, I., Wattiny, Pangerteni, D. S., Susilawati, S., 2020. Improvement of Bangka's white pepper quality using gamma irradiation technology: microbial contamination reduction. Journal of Physics: Conference Series. 1436, 012010. https://doi.org/10.1088/1742$6596 / 1436 / 1 / 012010$

de Farias, V.L., da Silva Araujo, I.M., da Rocha, R.F.J., dos Santos Garruti, D., Pinto, G.A.S., 2020. Enzymatic maceration of Tabasco pepper: Effect on the yield, chemical and sensory aspects of the sauce. WT - Food Science and Technology. 127, 1-8. https://doi.org/https://doi. org/10.1016/j.lwt.2020.109311

Dhas, P.H.A., Korikanthimath, V.S., 2003. Processing and quality of black pepper - a review. Journal of Spices and Aromatic Crops, 12, 1-13.

do Carmo, D.F.M., Amaral, A.C.F., Machado, G.M.C., Leon L.L., Silva, J.R. de A. 2012. Chemical and biological analyses of the essential oils and main constituents of Piper Species. Molecules, 17, 1819-1829. https:// doi.org/10.3390/molecules17021819

Favre, L.C., Rolandelli, G., Mshicileli, N., Vhangani, L.N., Ferreira, C., dos S., van Wyk, J., Buera, M., del P., 2020. Antioxidant and anti-glycation potential of green pepper (Piper nigrum): optimization of $\beta$-cyclodextrin-based extraction by response surface methodology. Food Chemistry. 316, 1-11. https://doi. org/https://doi.org/10.1016/j.foodchem.2020.126280

Feng, J., 2013. Screening and identification of an indigenous bacterial strain high active for fermentative production of white pepper (Piper nigrum L.).Advanced Materials Research. 781-784, 1489-1494. https://doi. org/10.4028/www.scientific.net/AMR.781-784.1489

Ferbiyanto,A., Rusmana, I., Raffiudin, R,.2015. Characterization and identification of cellulolytic bacteria from gut of worker Macrotermes gilvus. HAYATI Journal of Biosciences. 22, 197-200. https://doi.org/http:// dx.doi.org/10.1016/j.hjb.2015.07.001

Geron, L.J.V., de Souza, A.L., Zanin, S.F.P., de Aguiar, S.C., de Souza Santos, I., da Silva, R.F., ... de Jesus Ferreira, D., 2019. Pepper (Capsicum ssp.) as a feed additive in sheep rations using two types of inoculum: effects on in vitro digestibility and fermentation parameters. Semina: Ciências Agrárias, 40, 3653-3664. https://doi. org/10.5433/1679-0359.2019v40n6Supl3p3653

Hao, C., Fan, R., Qin, X., Hu, L., Tan, L., Xu, F., Wu, B.D., 2018. Characterization of volatile compounds in ten Piper species cultivated in Hainan Island, South China. International Journal of Food Properties. 21, 633-644. https://doi.org/10.1080/10942912.2018.1446147

Helianti, I., Ulfah, M., Nurhayati, N., Suhendar, D., Finalissari, A.K., Wardani, A.K., 2016. Production of xylanase by recombinant Bacillus subtilis DB104 cultivated in agroindustrial waste medium. HAYATI Journal of Biosciences. 23, 125-131. https://doi.org/http://dx.doi. org/10.1016/j.hjb.2016.07.002

Hidayat, T., Nurdjannah, N., Usmiati, S., 2009. Analisis teknis dan finansial paket teknologi pengolahan lada putih (White pepper) semi mekanis. Bul. Littro. 20, 77-91.

Hu, Q., Zhang, J., Xu, C., Li, C., Liu, S., 2017. The dynamic microbiota profile during pepper (Piper nigrum L.) peeling by solid-state fermentation. Curr. Microbiol. 74, 736-746. https://doi.org/10.1007/s00284-017$1242-\mathrm{X}$

Hunter Laboratories. 2012. Measuring color using Hunter L, a, b versus CIE L*, a*, b*. in: Hunter Laboratories, (Eds.), Hunter Associates Laboratory Inc: Reston.

Kaur, K., Gautam, A., 2019. Microbiological contamination of food: the sources , impacts and prevention. Journal of Agricultural Engineering and Food Technology. 6, $121-128$

Kusmiadi, R., Aini, S.N., Nurkholis., 2017. Analysis of mature and physiological aspects of soaking method physical and chemical white pepper (Muntok white pepper). Agrosaintek, 1, 39-48.

Li, Y., Zhang, C., Pan, S., Chen, L., Liu, M., Yang, K., ... Tian, J., 2020. Analysis of chemical components and biological activities of essential oils from black and white pepper (Piper nigrum L.) in five provinces of southern China. LWT - Food Science and Technology. 117m 108644. https://doi.org/https://doi.org/10.1016/j. lwt.2019.108644

Liu, H., Zeng, F.K., Wang, Q.H., Wu, H.S., Tan, L.H., 2013. Studies on the chemical and flavor qualities of white pepper (Piper nigrum L.) derived from five new genotypes. Eur. Food. Res. Technol. 237, 245-251. https://doi. org/10.1007/s00217-013-1986-X

Mamatha, B.S., Prakash, M., Nagarajan, S., Bhat, K.K., 2008. Evaluation of the flavor quality of pepper (Piper ningrum L.) cultivars by GC-MS, electronic nose and sensory analysis techniques. Journal of Sensory Studies. 23, 498-513. https://doi.org/10.1111/j.1745459X.2008.00168.X 
Megat, A.A.P.N., Shamsudin, R., Che Man, H., Ya'acob, M.E., 2019. Effect of soaking process on physical properties of mature pepper berries. Food Research. 4, 116-123.

Mohammadkazemi, F., Azin, M., Ashori, A., 2015. Production of bacterial cellulose using different carbon sources and culture media. Carbohydrate Polymers. 117, 518-523. https://doi.org/http://dx.doi.org/10.1016/j. carbpol.2014.10.008

Mustafa, D.S.B.A., Zulkharnain, A.B., AwangHusaini, A.A.S.B., 2015. Enzymatic retting of Piper nigrum L. using commercial pectinase (Peelzyme). Journal of Chemical and Pharmaceutical Sciencies. 8, 360-364.

Nedspice., 2015. Pepper Crop Report 2015: Summary of presentations at ASTA and ESA Annual Meeting.

Rathnawathie, M., Buckle, K.A., 1984. Effect of berry maturation on some chemical constituents of black, green and white pepper (Piper nigrum L.) from three cultivars. Journal of Food Technology. 19, 361-367. https://doi.org/10.1111/j.1365-2621.1984.tb00360.x

Rosnah, S., Chan, S., 2014. Enzymatic rettings of green pepper berries for white pepper production. International Food Research Journal. 21, 237-245.

Sasmitaloka, K.S., Hernani., 2020. Karakteristik fisikokimia lada putih hasil fermentasi menggunakan Bacillus subtilis. In: Prosiding Seminar Nasional Online "Peran Pangan Fungsional Dan Nutraseutikal.” Bogor: Balai Besar Penelitian dan Pengembangan Pascapanen Pertanian. pp. 225-231.

Sato, A., Astuti, D.I., Putri, S.P., Fukusaki, E., 2020. Quality improvement of semi-wet terasi by optimizing the starter culture ratio of controlled fermentation. HAYATI Journal of Biosciences. 27, 320-329. https:/| doi.org/10.4308/hjb.27.4.320

Singh, S., Kapoor, I., Singh, G., Schuff, C., De Lampasona, M., Catalan, C.A., 2013. Chemistry, antioxidant and antimicrobial potentials of white pepper (Piper nigrum L.) essential oil and oleoresins. Proceedings of the National Academy of Sciences, India Section B: Biological Sciences. 83, 357-366. https://doi. org/10.1007/s40011-012-0148-4

[SNI] Indonesian National Standards., 2013. SNI 0004:2013: Lada putih (SNI 0004: 2013: White pepper). Jakarta, Indonesia: Badan Standarisasi Nasional.

Song, C., Li, A., Chai, Y., Li, Q., Lin, Q., Duan, Y., 2019. Effects of 1-Methylcyclopropene combined with modified atmosphere on quality of Fig (Ficus carica L.) during postharvest storage. Journal of Food Quality. 2019, 1-9. https://doi.org/https://doi.org/10.1155/2019/2134924
Sreekala, G.S., Meenakumari, K.S., Vigi, S., 2019. Microbial isolate for the production of quality white pepper (Piper nigrum L.). Journal of Tropical Agriculture. 57, 114-121.

Steinhaus, M., Schieberle, P., 2005. Characterization of odorants causing an atypical aroma in white pepper powder (Piper nigrum L.) based on quantitative measurements and orthonasal breakthrough Thresholds. Journal of Agricultural and Food Chemistry. 53, 6049-6055. https://doi.org/10.1021/jf0506030

Thankamani, V.L., Giridhar, R.N., 2004. Fermentative production of white pepper using indigenous bacterial isolates. Biotechnology and Bioprocess Engineering. 9, 435-439. https://doi.org/10.1007/BF02933482

Usmiati, S., Nurdjannah, N., 2006. Pengaruh lama perendaman dan cara pengeringan terhadap mutu lada putih. Jurnal Teknologi Industri Pertanian. 16, 1-8.

van Ruth, S.M., Silvis, I.C.J., Ramos, M.E., Luning, P.A., Jansen, M., Elliott, C.T., Alewijn, M., 2019. A cool comparison of black and white pepper grades. LWT - Food Science and Technology. 106, 122-127. https://doi.org/10.1016/j. lwt.2019.02.054

Vinod, V., Kumar, A., Zachariah, T., 2014. Isolation, characterization and identification of pericarpdegrading bacteria for the production of off-odourfree white pepper from fresh berries of Piper nigrum $\mathrm{L}$. Journal of Applied Microbiology. 116, 890-902. https:/| doi.org/doi:10.1111/jam.12431

Waje, C.K., Kim, H.K., Kim, K.S., Todoriki, S., Kwon, J.H., 2008. Physicochemical and microbiological qualities of steamed and irradiated Ground Black Pepper (Piper nigrum L .). Journal of Agricultural and Food Chemistry 56, 4592-4596. https://doi.org/10.1021/jf8002015

Wang, J., Wang, R., Xiao, Q., Liu, C., Jiang, L., Deng, F., Zhou, H., 2019. Analysis of bacterial diversity during fermentation of Chinese traditional fermented chopped pepper. Letters in Applied Microbiology. 69, 346-352. https://doi.org/10.1111/lam.13212

Ye, J., Zheng, S., Zhang, Z., Yang, F., Ma, K., Feng, Y., Zheng, J. 2019. Bacterial cellulose production by Acetobacter xylinum ATCC 23767 using tobacco waste extract as culture medium. Bioresource Technology. 274, 518524. https://doi.org/10.1016/j.biortech.2018.12.028

Zhihao, D., Hu, Z., Jiancheng, P., Hui, X., Ai, H., Chao, W., 2011. Screening, identification and preliminary application of high efficient dehydration bacteria from pepper. China Condiment, 4, 51-55. 